\title{
EKSTRAK ANTOSIANIN DARI UBI UNGU (Ipomoea batatas L.) SEBAGAI PEWARNA ALAMI PADA SEDIAAN APUSAN DARAH TEPI
}

\author{
Anthocyanin from Sweet Potatoes (Ipomoea batatas L.) as Natural Stain at Peripheral \\ Blood Smear \\ ${ }^{1}$ Subakir Salnus, ${ }^{2}$ Dzikra Arwie \\ ${ }^{1,2}$ Sekolah Tinggi Ilmu Kesehatan Panrita Husada Bulukumba
}

Koresponden : akil.ladzinrank@gmail.com/082393644353

\begin{abstract}
The peripheral blood smear (SADT) is a human blood cell that is made smear and then stained in a hematology examination to assess various elements of peripheral blood cells such as erythrocytes, leukocytes and platelets. One guarantee of the validity of the results of the SADT examination is the quality of the SADT coloring. This study aims to investigate blood morphology in thin blood smears using anthocyanin extract from purple sweet potato as a natural dye for Giemsa dye. This research is an experimental laboratory by treating and comparing the morphological features of blood (erythrocytes, platelets and leucocytes) in thin blood smears using giemsa staining and using alternative staining of anthocyanin extract from purple sweet potato. Samples in the study using venous blood collected in a vacuum tube using EDTA anticoagulant were then made as a thin blood smear preparation. The results of this study indicated that only erythrosies had a fairly good staining quality, while the quality of the platelets and leucocytes was not good. The morphology of erythrocyte cells that are round or oval and from the side is like a disc (bikonkaf) with a central acromia (pale color). Furthermore, several abnormalities of erythrocyte cell are obtained such as elliptocytes (ovalocytes), schistocytes (helmet cell) and burr cell so that the anthocyanin extract in purple sweet potato has the potential as an alternative stain for erythrocyte cells in peripheral blood smears.
\end{abstract}

Keywords : Anthocyanin, Erythrocite, Staining

\begin{abstract}
ABSTRAK
Sediaan Apus Darah Tepi (SADT) merupakan sel darah manusia yang dibuat apusan kemudian diwarnai dalam pemeriksaan hematologi untuk menilai berbagai unsur sel darah tepi seperti eritrosit, leukosit dan trombosit. Salah satu jaminan validitas hasil pemeriksaan SADT adalah kualitas pewarnaan SADT. Penelitian ini bertujuan untuk mengamati morfologi sel darah pada sediaan apusan darah tipis menggunakan ekstrak antosianin dari ubi ungu sebagai pewarna alami pengganti pewarna Giemsa. Penelitian ini merupakan eksperimen laboratorium dengan cara mengamati dan membandingkan gambaran morfologi sel darah (eritrosit, trombosit dan leukosit) pada sediaan apusan darah tipis menggunakan pewarnaan giemsa dan menggunakan pewarnaan alternatif ekstrak antosianin dari ubi ungu. Sampel pada penelitian ini menggunakan darah vena yang ditampung pada tabung vakum menggunakan antikoagulan EDTA kemudian dibuat sebagai preparat apusan darah tipis. Hasil penelitian ini menunjukkan hanya eritrosi yang memiliki kualitas pewarnaan yang cukup baik sedangkan kualitas pewarnaan trombosit dan leukosit kurang baik. Adapun morfologi sel eritrosit normal yang diperoleh berbentuk
\end{abstract}


diskoid, bulat atau oval dan dari samping seperti cakram (bikonkaf) dengan sentral akromia (berwarna pucat). Selain itu, diperoleh beberapa bentuk kelainan sel eritrosit seperti eliptosit (ovalosit), sel skistosit/helmet dan sel burr sehingga ekstrak antosianin pada ubi ungu memiliki potensial sebagai pewarnaan alternatif untuk sel eritrosit pada sediaan apusan darah tepi.

Kata kunci : Antosianin, Eritrosit, Pewarnaan

\section{PENDAHULUAN}

Darah adalah suatu jaringan tubuh yang berada pada kondisi konsistensi cair menyerupai sirup dengan berat jenis 1,055 dan memiliki kekentalan dua setengah kali dari air. Darah beredar dalam tubuh melalui suatu sistem tertutup (pembuluh darah). Fungsi darah yaitu sebagai alat transpor serta hemostasis. Sel darah putih (leukosit) adalah sel yang terdapat dalam darah, yang memiliki fungsi sebagai pertahanan tubuh terhadap benda asing. Biasanya leukosit tidak hanya satu jenis, tapi ada 5 jenis leukosit yang terdapat dalam darah normal (Bain, 2017). Pada pemeriksaan sel darah secara mikroskopik dapat diamati jenis sel darah merah (eritrosit), sel darah putih (leukosit) serta keping darah (trombosit).

Hematologi merupakan bidang studi kesehatan yang mempelajari tentang kodisi darah yang meliputi komponen darah, fungsi darah, struktur darah, dan pembentukan darah. Merupakan suatu pemeriksaan untuk mengidentifikasi masalah dengan berbagai tes darah diagnostik laboratorium klinis untuk mendiagnosa suatu kondisi pasien. Pemeriksaan dengan teknik mikroskopik yang berfungsi untuk mengamati morfologi sel darah bahkan komponen lain yang dapat memberikan informasi yang cukup banyak dan bermakna terhadap keadaan hematologi seseorang (Nugraha, 2017).

Sediaan apusan darah tepi (SADT) merupakan sel darah manusia yang dibuat apusan kemudian diwarnai dalam pemeriksaan hematologi untuk menilai berbagai unsur sel darah tepi seperti eritrosit, leukosit dan trombosit. Salah satu jaminan validitas hasil pemeriksaan SADT adalah kualitas pewarnaa SADT. Terdapat beberapa metode pewarnaan SADT yang dianjurkan oleh The International Council For Stadardization in Hematology seperti Wright's stain, Lieshman, May-Grünwald, dan pewarnaan Giemsa (Nugraha, 2015).

Pewarnaan Giemsa paling umum digunakan, tetapi Giemsa memiliki kelemahan, yaitu kurang kuat mewarnai granula sel-sel seri granulosit. Selain itu, kandungan methylen blue, eosin, dan azur B bersifat tidak mudah terurai, dan menimbulkan limbah yang berbahaya (toxic) serta mudah terbakar (flameable). Di era global saat ini, kesadaran masyarakat terhadap bahan bersifat organik dan berasal dari alam yang ramah lingkungan (eco-friendly) lebih tinggi, sehingga diperlukan alternatif metode pewarnaan menggunakan bahan alami, seperti dengan pemanfaatan zat pewarna alami antosianin yang berasal dari ekstrak ubi ungu. Shuebkampet (2011) telah menggunakan ekstrak bunga kertas (Butterfly-pea) untuk mewarnai sel darah ayam, anjing, kuda, dan merpati, hal ini membuktikan bahwa antosianin dapat digunakan sebagai pewarna SADT. Ubi jalar ungu memiliki kandungan pigmen antosianin yang tinggi dan lebih stabil daripada pigmen stroberi, kubis merah, perilla dan tumbuhan lainnya. Dengan demikian, ubi jalar ungu telah dianggap sebagai sumber antosianin yang baik (Khoo, 2017). 


\begin{abstract}
Proses ekstraksi merupakan suatu teknik pemisahan suatu zat berdasarkan perbedaan distribusi kelarutannya (zat terlarut) terhadap dua cairan pelarut atau lebih yang saling bercampur. Sedangkan proses maserasi merupakan teknik pemisahan zat target dengan zat sisa berdasarkan prinsip kepolaran dimana zat target akan terlarut kedalam pelarut yang memiliki sifat polaritas yang sesuai dengan zat target.
\end{abstract}

\section{METODE}

\section{Desain, tempat dan waktu}

Jenis penelitian yang digunakan adalah penelitian deskriptif, yaitu mengamati dan membandingkan gambaran morfologi sel darah (eritrosit, leukosit dan trombosit) pada sediaan apusan darah tipis menggunakan pewarnaan giemsa dan pewarnaan alternatif antosianin dari ubi ungu. Penelitian ini dilakukan di Laboratorium Analis Kesehatan Stikes Panrita Husada Bulukumba pada bulan AgustusSeptember 2020.

Metode pengambilan sampel dalam penelitian ini dilakukan dengan cara Simple Random Sampling (secara acak). Populasi pada penelitian ini adalah darah vena seluruh mahasiswa Prodi DIII Analis Kesehatan Stikes Panrita Husada Bulukumba sebanyak 229 orang. Sampel dalam penelitian ini adalah darah vena yang diambil dari mahasiswa program studi DIII Analis Kesehatan Stikes Panrita Husada Bulukumba berjumlah 30 orang.

\section{Langkah-Langkah Penelitian}

1. Pembuatan Ekstrak Antosianin

Pembuatan ekstrak antosianin dari ubi ungu dilakukan dengan cara melarutkan parutan ubi ungu kedalam pelarut metanol- $\mathrm{HCl}(\mathrm{pH}$ 4) dan direndam selama 1x24 jam. Maserat yang diperoleh selanjutnya dipekatkan dengan cara menguapkan pelarutnya sehingga diperoleh ekstrak pekat antosianin. Pembuatan varian konsentrasi pewarna antosianin dilakukan dengan cara melarutkan ekstrak pekat kedalam akuabides dengan perbandingan berdasarkan rumus pengenceran $(\mathrm{M} 1 . \mathrm{V} 1=\mathrm{M} 2 . \mathrm{V} 2)$ sehingga diperoleh konsentrasi 10, 20, 40, 60, 80 dan 100\%.

2. Pengambilan Sampel Darah Vena

Pengambilan sampel darah vena menggunakan tabung vakum berisi antikoagulan EDTA dilakukan dengan cara meletakkan lengan pasien pada posisi lurus dan siku tidak dibengkokkan. Dipilih lengan yang paling sering melakukan aktivitas. Pasien diminta untuk mengepalkan tangan lalu memasang tourniquet sekitar $\pm 10 \mathrm{~cm}$ di atas lipat siku (tidak lebih dari 1 menit). Selanjutnya dipilih bagian vena mediana cubiti. Bersihkan permukaan kulit yang akan diambil darahnya dengan kapas alkohol $70 \%$ dan dibiarkan kering (jangan disentuh lagi). Bagian vena tadi ditusuk dengan lubang jarum menghadap keatas dengan sudut kemiringan antara jarum dan kulit adalah $15^{\circ}$. menekan tabung vakum sehingga darah terisap ke dalam tabung. Selanjutnya melepaskan tourniquet dan pasien diminta untuk melepaskan kepalan tangan. Biarkan darah mengalir ke dalam tabung sampai selesai. Jarum ditarik lalu meletakkan kapas di atas bekas tusukan tersebut selama \pm 2 menit. Setelah darah berhenti, kemudian bagian ini diplester selama \pm 15 menit.

3. Pembuatan Preparat Apusan Darah Tepi

Darah pada tabung vakum EDTA terlebih dahulu dikocok keatas dan kebawah agar plasma darah dapat bercampur dengan sel-sel darah. Darah lalu diambil menggunakan pipet tetes dan diteteskan pada preparat (obyek glass). Selanjutnya obyek glass 
diletakkan pada sudut $25^{\circ}-30^{\circ}$ pada tetesan darah, kemudian ditarik lurus sampai ujung preparat hingga membentuk apusan yang tipis.

4. Pewarnaan preparat Apusan Darah Tepi menggunakan pewarnaan giemsa (kontrol)

Proses fiksasi dilakukan dengan meneteskan metanol ke atas preparat dan dibiarkan selama 5 menit. Lalu membuang sisa metanol. Selanjutnya tahap pewarnaan dilakukan dengan meneteskan larutan giemsa hingga semua apusan tergenangi dan dibiarkan selama 15-30 menit. Preparat dibilas dengan air kemudian dikeringkan di udara.

5. Pewarnaan preparat Apusan Darah Tepi menggunakan pewarnaan ekstrak antosianin

Proses fiksasi dilakukan dengan meneteskan metanol ke atas preparat dan dibiarkan selama 5 menit. Lalu membuang sisa metanol. Selanjutnya tahap pewarnaan dilakukan dengan meneteskan ekstrak antosianin konsentrasi $100 \%$ hingga semua apusan tergenangi dan dibiarkan selama 15-30 menit. Preparat dibilas dengan air kemudian dikeringkan di udara.

Proses pembuatan preparat dengan variasi ekstrak antosianin pada konsentrasi $80-10 \%$ menggunakan prosedur yang sama seperti diatas.

6. Pengamatan dibawah mikroskop

Preparat yang telah dibuat kemudian diberi minyak imersi lalu diamati dibawah mikroskop dengan perbesaran 100x.

\section{Pengolahan dan analisis data}

Data yang diperoleh dari penelitian ini disajikan dalam bentuk data deskriptif kualitatif berupa gambaran morfologi sel darah di deskripsikan secara subjektif berdasarkan gambaran yang ditampilkan pada pengamatan dibawah mikroskop.

\section{HASIL}

Hasil penilaian pewarnaan SADT meliputi penilaian secara mikroskopik ditunjukkan pada gambar 1 dan 2. Pada pewarnaan SADT menggunakan pewarnaan ekstrak antosianin variasi konsentrasi menunjukkan kualitas gambaran terbaik pada konsentrasi $80 \%$. Sedangkan pada variasi ekstrak antosianin konsentrasi 10, 20, 40 dan 60\% gambaran sel darah yang ditunjukkan kurang jelas yaitu hasil pewarnaan pucat dan latar belakang pucat. Untuk variasi ekstrak antosianin konsentrasi $100 \%$ memiliki gambaran sel darah dengan hasil pewarnaan terlalu tebal dan latar belakang yang gelap. Adapun sel darah yang dapat diamati berdasarkan morfologi sel darah secara mikroskopik, hanya eritrosi yang memiliki kualitas pewarnaan yang cukup baik dimana morfologi sel eritrosit yang diperoleh berbentuk bulat atau oval dan dari samping seperti cakram (bikonkaf) dengan sentral akromia (berwarna pucat), lapang pandang bersih tanpa sisa zat pewarna, dan sel-sel yang ditunjukkan tidak saling tumpang tindih. Sedangkan kualitas pewarnaan trombosit dan leukosit kurang jelas sehingga gambaran yang diperoleh kurang baik.

\section{PEMBAHASAN}

$\begin{array}{llr}\quad \text { Pada } & \text { pewarnaan } & \text { SADT } \\ \text { menggunakan } & \text { pewarnaan } & \text { ekstrak } \\ \text { antosianin } & \text { variasi konsentrasi }\end{array}$ menunjukkan kualitas gambaran terbaik pada konsentrasi $80 \%$, hal ini kemungkinan disebabkan karena jumlah komponen senyawa antosianin dapat saling berinteraksi dengan sel eritrosit dengan baik, selain itu sifat keasaman pada senyawa antosianin yang memiliki kecenderungan kesesuaian dengan keadaan asam pada eritrosit membuat interaksinya semakin baik. Pada keadaan 
ini, senyawa antosianin dapat terikat dengan baik di bagian permukaan dari sel eritrosit sehingga sel eritrosit dapat teramati dengan baik dibawah pengamatan miksorkop.

Pada pewarnaan ekstrak antosianin variasi konsentrasi $100 \%$, memiliki keadaan lapangan pandang yang kurang jelas dimana sel eritrosit terwarnai dengan sangat tebal dan tampak saling bertumpuk sehingga kurang baik teramati dibawah mikroskop. Selain itu latar belakang yang cukup gelap kemungkinan disebabkan oleh pewarnaan ekstrak antosianin yang masih tersisa pada saat pembilasan.

Berdasarkan penelitian ini, semua konsentrasi ekstrak antosianin pada SADT tidak dapat mengamati trombosit dan leukosit. Hasil yang diamati berupa lapang pandang yang terlihat buram, pucat atau kecoklatan sehingga tidak didapatkan sel trombosit dan leukosit. Hal ini dikarenakan $\mathrm{pH}$ asam dari larutan mendegradasi membran sel trombosit dan leukosit, sehingga leukosit menjadi rusak dan tidak terwarnai, namun hanya sel ertirosit yang dapat terwarnai dalam keadaan larutan yang asam karena sel eritrosit lebih tahan terhadap asam. Pewarna giemsa memiliki sifat pewarna kation (basa) azure B yang berfungsi untuk mewarnai trombosit dan warna biru-ungu pada nukleuprotein, granula basofil dan granula neutrophil. Selain itu, pewarna giemsa juga memiliki sifat pewarna anion (asam) seperti Eosin Y yang dapat memberikan warna merah atau orange pada eritrosit dan granula eosinofil serta mewarnai inti sel (McKenzie, 2014).

Selain morfologi eritrosit normal, hasil pengamatan juga diperoleh beberapa bentuk kelainan sel eritrosit seperti eliptosit (ovalosit), sel skistosit/helmet dan sel burr.

\section{KESIMPULAN}

Penggunaan pewarna alami ekstrak antosianin dari ubi ungu pada Sediaan apusan darah tepi menunjukkan sel darah merah (eritrosit) yang cukup baik namun tidak dapat mewarnai trombosit dan leukosit sehingga ekstrak antosianin memiliki potensi untuk digunakan sebagai pewarna alternatif pada pengamatan sel darah merah (eritrosit).

\section{SARAN}

Sebaiknya melakukan penelitian lebih lanjut mengenai penambahan komponen zat pewarna pada ekstrak antosianin yang ingin dijadikan sebagai pewarna terhadap sel leukosit dan trombosit.

\section{UCAPAN TERIMA KASIH}

Ucapan terima kasih diberikan kepada ketua Yayasan Panrita Husada Bulukumba, ketua STIKES Panrita Husada Bulukumba, Laboratorium Analis Kesehatan serta seluruh pihak yang telah membantu tim peneliti menyelesaikan penelitian ini.

\section{DAFTAR PUSTAKA}

Bain, Barbara Jane. 2017. Hematologi Kurikulum Inti. EGC.

Khoo, H.E., Azlan, A., Tang, S.T., Lim, S.M. 2017. Anthocyanidins and anthocyanins: colored pigments as food, pharmaceutical ingredients, and the potential health benefits. Food Nutr. Res. 61, 1654-1661.

McKenzie, S.B. 2014. Clinical Laboratory Hematology. Pearson Education Inc. New Jersey.

Nugraha, G. 2015. Panduan Praktikum Laboratorium Hematologi Dasar. Jakarta. Trans Info Media.

Nugraha, G. 2017. Panduan pemeriksaan Laboratorium Hematologi Dasar (A. M@ftuhin (Ed.); 2nd ed.). CV. Trans Info 
Media.

Suebkhampet, A. dan Sotthibandhu, P. 2012. Effect of Using Aqueous Crude Extract from Butterfly Pea Flower (Clitoria ternatea L.) as a
Dye on Animal Blood Smear Staining. Suranae Journal of Science Technology. 19(1): 15-19. Thailand. 

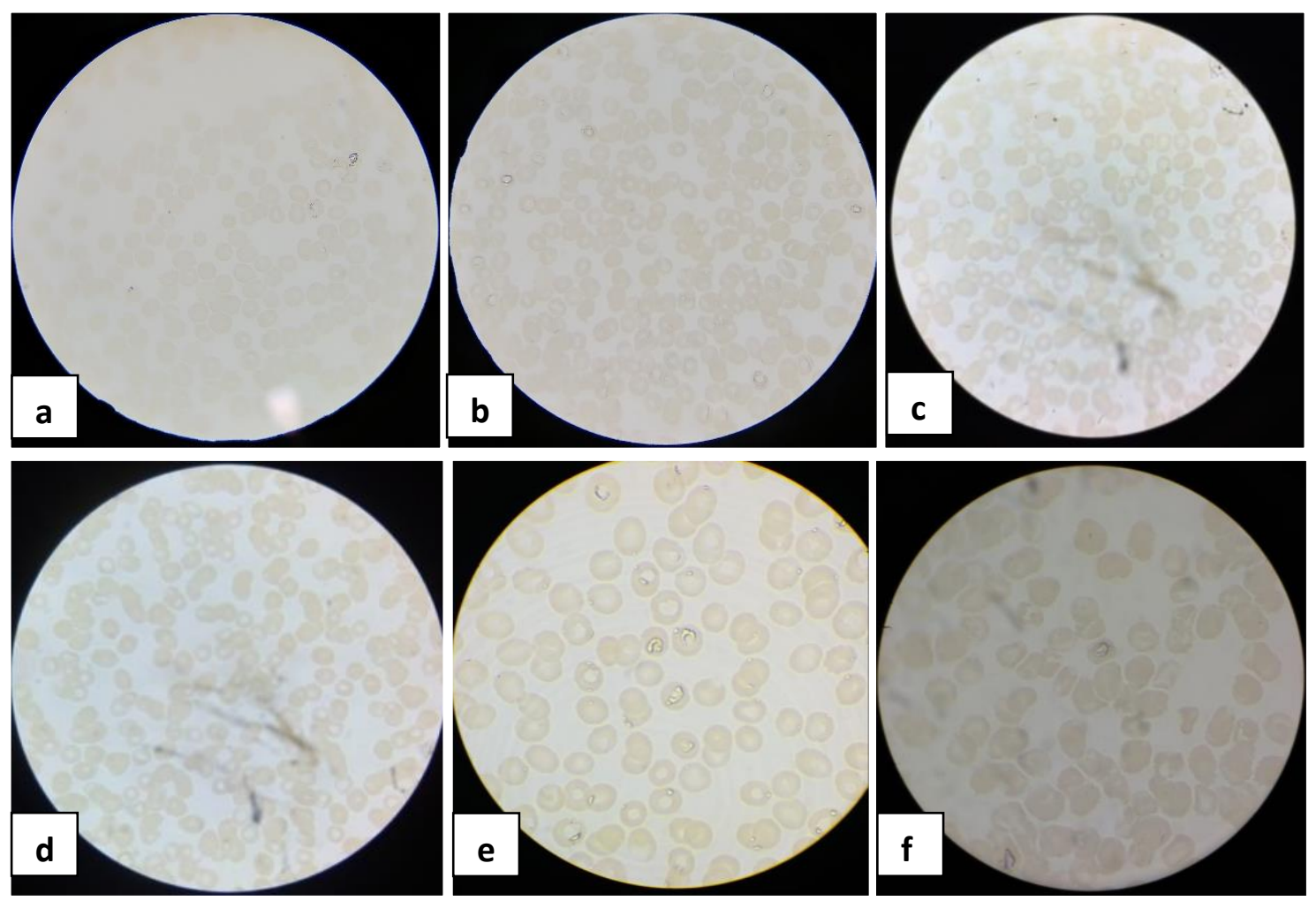

Gambar 1 Hasil Pengamatan Sediaan Apusan Darah Tepi Pewarnaan Ekstrak Antosianin Variasi Konsentrasi Secara Mikroskopik Perbesaran 100x (a) Konsentrasi 10\%, (b) Konsentrasi 20\%, (c) Konsentrasi 40\%, (d) Konsentrasi 60\%, (e) Konsentrasi 80\% Dan (F) Konsentrasi 100\%.
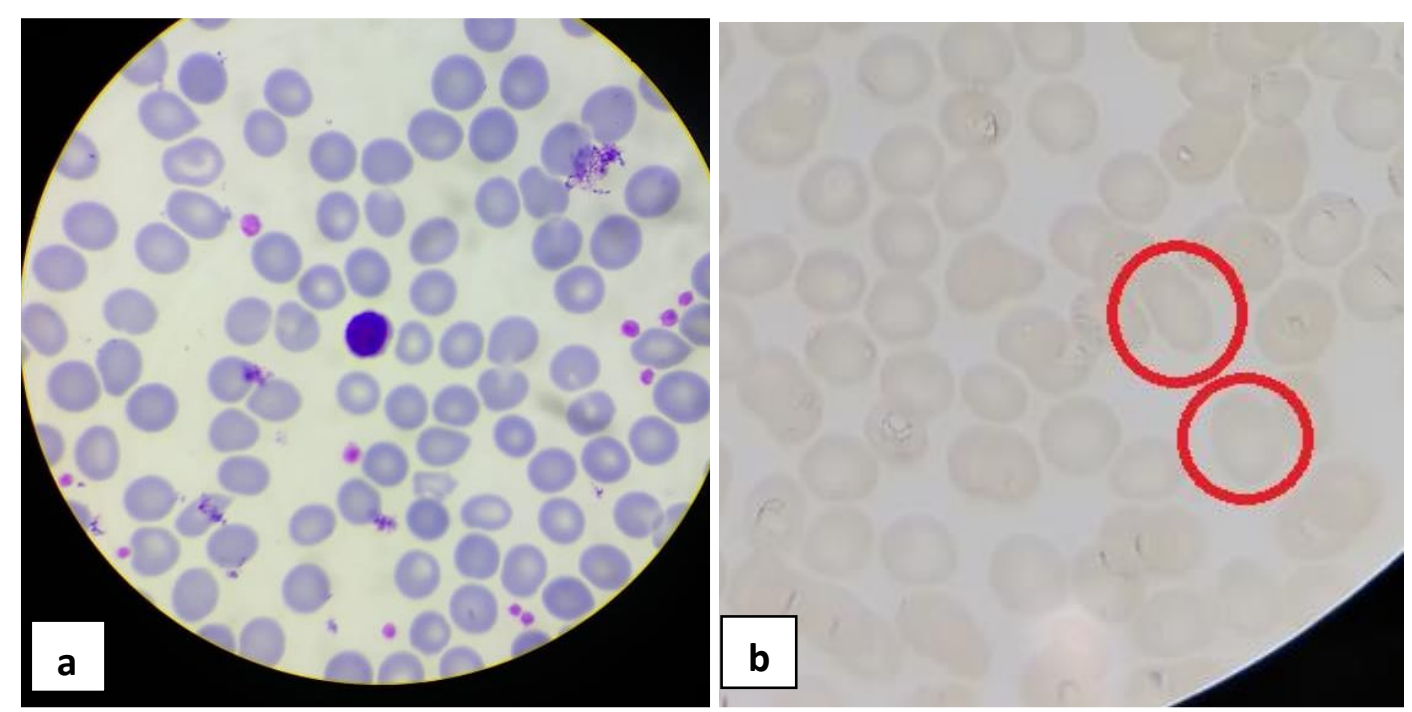


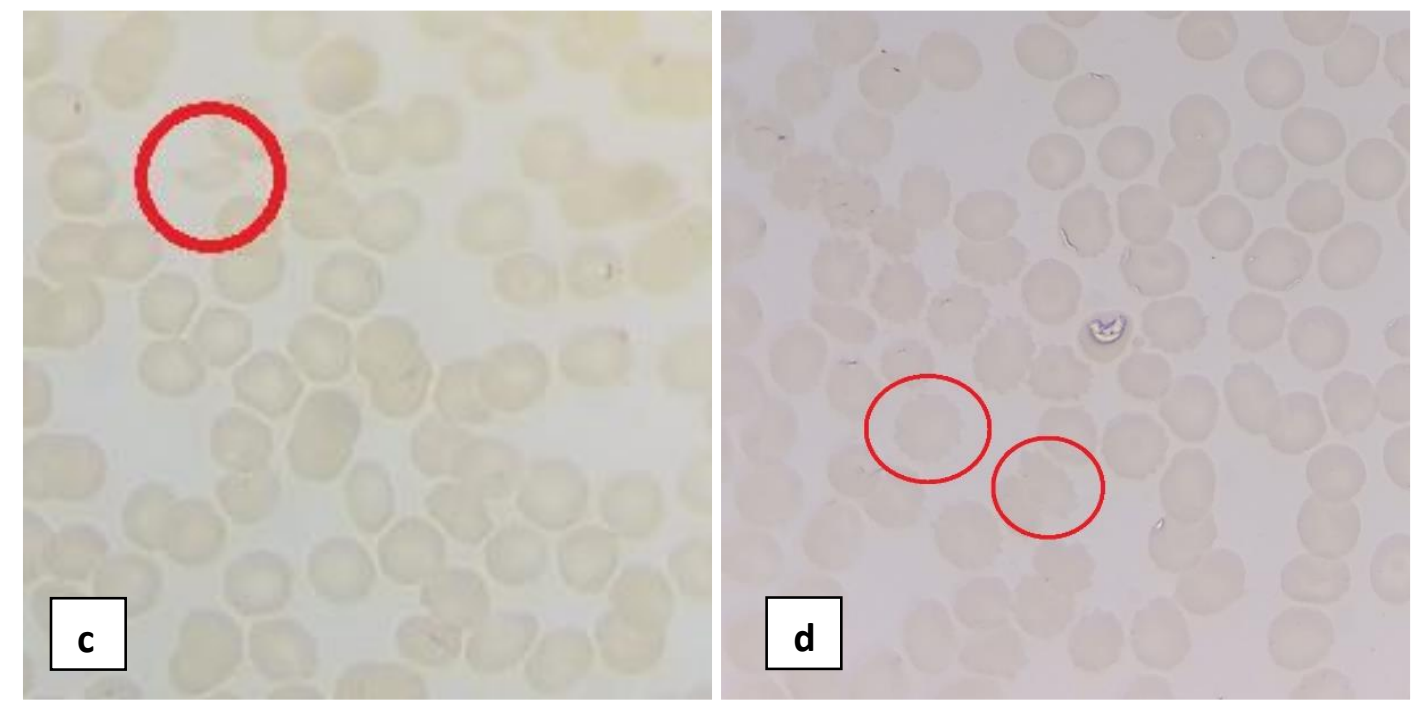

Gambar 2 Hasil Pengamatan SADT (a) Pewarnaan Giemsa 10\%, (b) Kelainan Bentuk Eritrosit Eliptosit/Ovalosit, (c) Kelainan Bentuk Eritrosit Skistosit/Helmet, (d) Kelainan Bentuk Eritrosit Sel Burr. 